Original Article

\title{
Study on Awareness about Self-Medications and it's Complications Among Homemakers
}

\section{Suchithra B.S.}

Assitant Professor, Nitte Usha Institute of Nursing Sciences, Paneer, Mangalore.

*Corresponding Author : Suchithra B.S., Asst. Professor, Nitte Usha Institute of Nursing Sciences, Paneer, M angalore - 574160. Mobile : +919980185750 E-mail : suchibs@yahoo.co.in

$\begin{array}{ll}\text { Received } & : 01.12 .2016 \\ \text { Review Completed } & : 25.01 .2017 \\ \text { Accepted } & : 28.01 .2017\end{array}$

Keywords : self-medication, homemaker, awareness, prevalence.

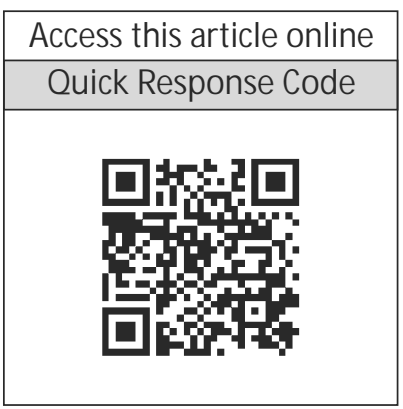

\begin{abstract}
Self-medication is mostly advanced practice worldwide and often considered as a component of self-care .However, unlike other components of self-care, self-medication has the potential to do good as well as cause harm since it involves the use many kinds of drugs. The practice of selfmedication must be based on authentic medical information otherwise irrational use of drugs can cause wastage of resources, increased resistance of pathogens, and also can lead to serious health hazards such as adverse drug reaction and prolonged morbidity
\end{abstract}

\section{Objectives of the study}

1. To assess the occurrence of self-medication among homemakers.

2. To find the level of awareness and it's complications of self-medication among the homemakers.

\section{Research methodology of the study}

Research design for the present study is descriptive research design. The design was used to assess the prevalence of self-medication among homemakers and their awareness about selfmedication and its complications, at selected areas in Nitte village. The purposive sampling technique is used to select samples for the study. Sample size was about 100 homemakers and the population belonged to selected areas in Nittte village.

\section{Results}

The result shows out of 100 homemakers 85 were having the habit of taking self- medication, remaining 15 were not consuming.

Out of 85 homemakers, who are practicing self medication only 3.529\%(3) are having good level of awareness, $45.882 \%(39)$ are having average knowledge, $50.588 \%(43)$ are having poor knowledge.97.647\%(83) are practicing self medication for fever and $2.352 \%(2)$ are not taking.54.117\%(46) are practicing self medication for head ache, 3.529\%930 are not taking.3.529\%(3) are practicing self medication for vomiting, $96.470 \%(82)$ are not taking. $2.352 \%$ (2) are taking self medication for diarrhea and $97.647 \%(83)$ are not taking.28.235\%(24) are taking self medication for dysmenorrheal and $71.764 \%(61)$ are not taking. $40 \%(34)$ are taking self medication for cough and $60 \%(51)$ are not taking.

The method of procurement of medicines used for self medications are mainly previous prescription among 41.176\%(37), 55.294\%(47) are taking self medication by remembering names and $1.176 \%(1)$ are self medication by storing drugs at are using self medication frequently.7.058\%(6) are using self medication occasionally, 1.176\%(1) are using very frequently.

\section{Introduction}

According to WHO self-medication is defined as the selection and the use of medicines by individuals to treat self recognized illness or symptoms. Self-medication is one element of self-care. Self-medication can take place through the consumption of industrialized or manipulated medicines or the use of home remedies (teas, herbs etc) and include various type of activities - acquiring medicines without prescription, resubmitting old prescriptions to purchase medicines, sharing medicines with relatives or member of one social circle, using left over medicines stored at home or failing to comply with professional prescription either by prolonging it or interrupting it too early or decreasing or increasing the originally prescribed dosage.

Medications are one of the main options in the cure, treatment, and prevention of numerous medical 
conditions. Intact, medications are the primary treatment client associate with restoration of health.

The consumption of medications can be considered an indirect indicator of the quality of health care services. Children and adolescent s are strongly susceptible to the irrational use of drugs with and without medical control. Economic political and cultural factors have contributed to the growth and spread of self-medication worldwide. These factors are related with aspects such as the great availability of products in the current days; the state of health that a pharmaceutical agent may represent; irresponsible publicity; pressure to convert prescription - only drugs; quality of health care ; difficult access to health care services in poor countries.

\section{Statement of the problem}

A descriptive study on awareness about self-medications and it's complications among homemakers at selected areas in NITTE village.

\section{Objectives of the study}

1. To assess the occurrence of self-medication among homemakers.

2. To find the level of awareness and it's complications of self-medication among the homemakers.

\section{Research approach}

Research approach indicates the basic procedure for conducting research. In this study descriptive study approach, which is coming under quantitative approach is adopted.

\section{Research design}

Research deign is a blue print for conducting a study. It refers to the researcher's overall plan for obtaining answer to the research questions for testing the research hypothesis. In this study descriptive research design was selected, which is a descriptive survey design was adopted.

\section{Setting of the study}

The setting is where the population or the sample being studied is located and where the study is carried out. The study was conducted at selected areas in NITTE village.

\section{Population}

Population consists of the entire set of individuals having some common characteristics sometimes refers to as universe. In the present study population consists of homemakers at selected areas in NITTE village.

\section{Sample}

A sample is a subset of a population selected to participate in research study. The sample for the study comprised of 100 homemakers from the population aged above 25 years who are residing at selected areas in NITTE village.

\section{Samplingtechniques}

Sampling technique is a process of selecting subjects who are representatives of the population being studied. For the present study purposive sampling technique was chosen for the study which comes under non-probability sampling technique.

\section{Sampling criteria}

The following criteria were set for the selection of the sample:

\section{Instruments used}

Research instruments are the devices used to collect data.

Followingare the tools used in the present study:

1. Demographic proforma.

2. Checklist to assess the prevalence of self-medication and the level of awareness about self-medication and it's complications among homemakers.

\section{Data collection process}

Data was collected from 100 homemakers residing at selected areas in NITTE village. The purpose of the study was explained to the homemakers. Informed written consent was obtained. Confidentiality was assured to all subjects to get their cooperation. A total of 100 who followed the inclusion criteria were taken for the study, sample were collected by using purposive sampling technique. Then the tool was administered to the mothers and it was explained. The mothers were encouraged to clarify their doubts. 


\section{Results}

Fig. 1 : Reason for using self-medication

The present study revealed that out of 85 homemakers 22 are practicing self-medication because of lack of time, while 53 because of mild illness and 10 due to emergency situations

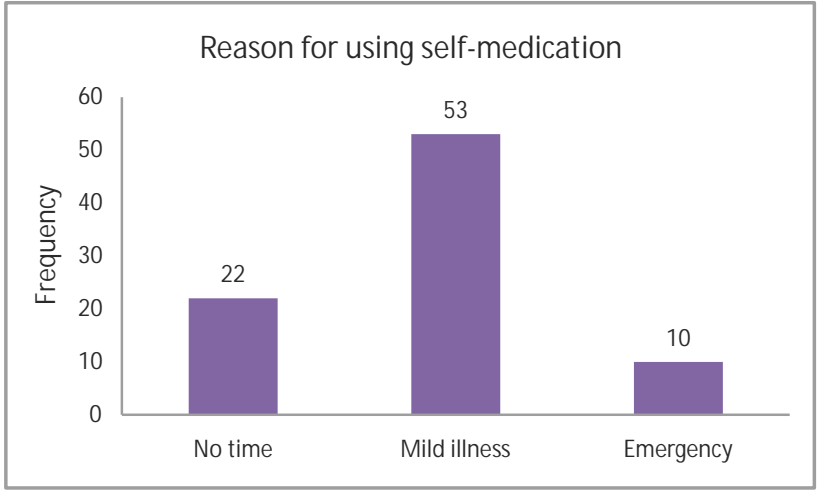

Fig. - 2: Bar diagram showing method of procurement of medicines used for Self-medication among homemakers $(n=85)$.

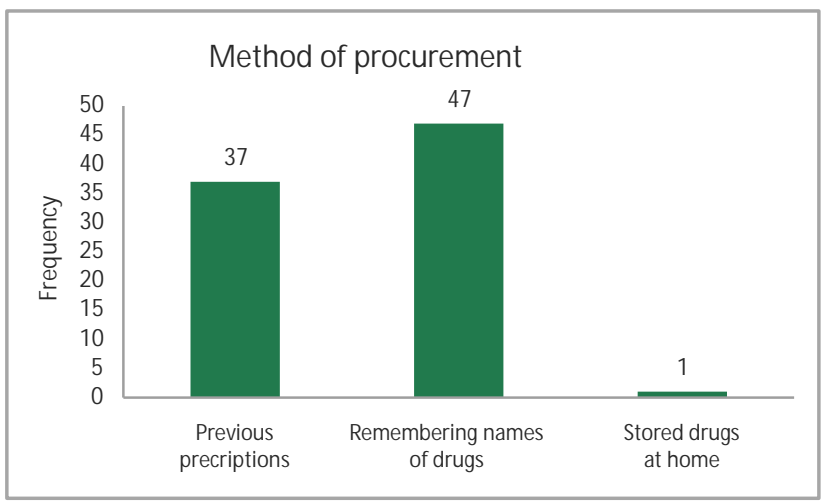

\section{Fig. 3 : Sources of drugs for self-medication}

The present study revealed that out of 85 homemakers 82 are using previous prescriptions for obtaining medications and 3 from their friends.

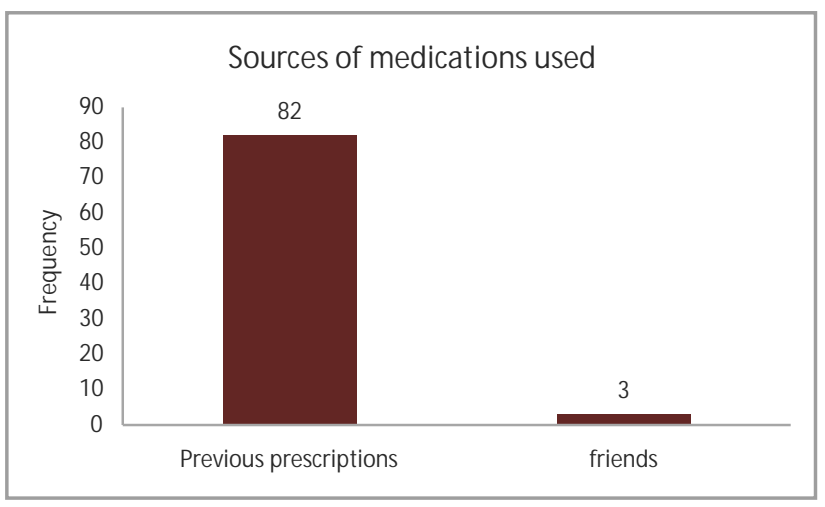

\section{Fig. 4 : Frequency of self-medication}

The present study revealed that out of 85 homemakers, only 1 is practicing self-medication very frequently, 78 are practicing frequently and 6 are taking self-medications occasionally.

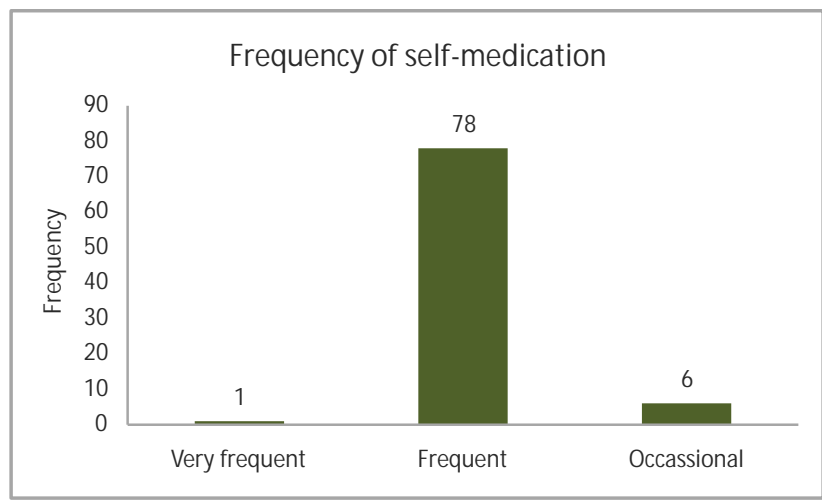

Fig. 5 : Prevalence of self medication

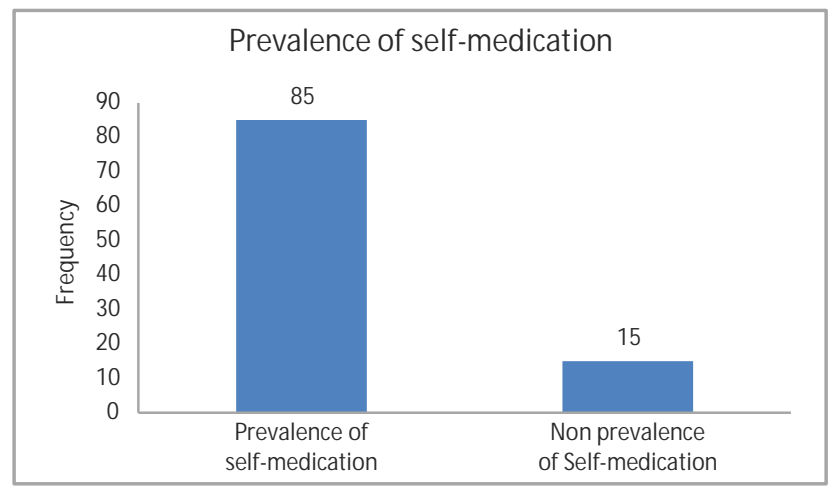

Table 1 : Distribution of demographic characteristics of the subjects

\begin{tabular}{|c|c|c|c|}
\hline \multicolumn{2}{|c|}{$\begin{array}{l}\text { Demographic characteristics } \\
(\mathrm{n}=100)\end{array}$} & Frequency & $\begin{array}{l}\text { Percentage } \\
\text { (\%) }\end{array}$ \\
\hline \multirow{4}{*}{ Age ( yrs) } & Less than 30 & 18 & 18 \\
\hline & $31-40$ & 45 & 45 \\
\hline & $41-50$ & 16 & 16 \\
\hline & More than 51 & 21 & 21 \\
\hline M arital status & Married & 100 & 100 \\
\hline \multirow{3}{*}{ Educational status } & No formal & 26 & 26 \\
\hline & Primary & 69 & 69 \\
\hline & Higher primary & 5 & 5 \\
\hline Area of residence & Rural & 100 & 100 \\
\hline \multirow{2}{*}{ Type of family } & Nuclear & 55 & 55 \\
\hline & Joint & 45 & 45 \\
\hline
\end{tabular}

Description of the sample characteristics were based on age of the mother, marital status educational status, area of residence and type of family. 
Table 2 : Reported Practice of self-medication

$(n=85)$

\begin{tabular}{|c|c|c|}
\hline Diseases & Practice of self medication & Frequency \\
\hline \multirow[t]{2}{*}{ Fever } & Not taking medication & 2 \\
\hline & Taking medications & 83 \\
\hline \multirow[t]{2}{*}{ Headache } & Not taking medication & 39 \\
\hline & Taking medication & 46 \\
\hline \multirow[t]{2}{*}{ Vomiting } & Not taking medication & 82 \\
\hline & Taking medication & 3 \\
\hline \multirow[t]{2}{*}{ Diarrhea } & Not taking medication & 83 \\
\hline & Taking medication & 2 \\
\hline \multirow[t]{2}{*}{ Dysmenorrheal } & Not taking medication & 61 \\
\hline & Taking medication & 24 \\
\hline \multirow[t]{2}{*}{ Cough } & Not taking medication & 51 \\
\hline & Taking medication & 34 \\
\hline \multirow{4}{*}{$\begin{array}{l}\text { Reason for } \\
\text { using self } \\
\text { medication }\end{array}$} & No time & 22 \\
\hline & Mild illness & 53 \\
\hline & Emergency & 10 \\
\hline & Previous good response & 0 \\
\hline \multirow{4}{*}{$\begin{array}{l}\text { M ethod of } \\
\text { procurement }\end{array}$} & Previous prescriptions & 37 \\
\hline & Remembering names of drugs & 47 \\
\hline & Stored drugs at home & 1 \\
\hline & Telling symptoms to pharmacist & 0 \\
\hline \multirow{3}{*}{$\begin{array}{l}\text { Source of } \\
\text { medication } \\
\text { used }\end{array}$} & Previous prescriptions & 82 \\
\hline & Friends & 3 \\
\hline & Relatives & 0 \\
\hline \multirow{3}{*}{$\begin{array}{l}\text { Frequency of } \\
\text { self-medication }\end{array}$} & Very frequent & 1 \\
\hline & Frequent & 78 \\
\hline & Occasional & 6 \\
\hline
\end{tabular}

Table 3 : Level of awareness of self medication among homemakers.

\begin{tabular}{|l|c|c|}
\hline \multirow{2}{*}{ Level of awareness } & \multicolumn{2}{|c|}{ Frequency } \\
\cline { 2 - 3 } & YES & NO \\
\hline Are you taking any self - medication? & 85 & 15 \\
\hline $\begin{array}{l}\text { Do you buy medication from nearby: } \\
\text { Pharmacy }\end{array}$ & 85 & 0 \\
\hline $\begin{array}{l}\text { Do you seek advice from neighbors, friends, } \\
\text { and relatives before consuming medications } \\
\text { apart from doctors? }\end{array}$ & & \\
\hline $\begin{array}{l}\text { Do you consume any other medication } \\
\text { apart from allopathic medication? }\end{array}$ & 77 & 8 \\
\hline $\begin{array}{l}\text { Whether you watch advertisements } \\
\text { before taking medications? }\end{array}$ & 76 & 9 \\
\hline $\begin{array}{l}\text { Do you consider the dosage before } \\
\text { taking medications? }\end{array}$ & 19 & 66 \\
\hline $\begin{array}{l}\text { Do you follow the instructions of the } \\
\text { doctor, given during the last visit } \\
\text { for similar illness? }\end{array}$ & 18 & 67 \\
\hline $\begin{array}{l}\text { Do you have the habit of stocking } \\
\text { emergency medications? }\end{array}$ & 63 & 22 \\
\hline $\begin{array}{l}\text { Do you have the habit of taking } \\
\text { medications without any } \\
\text { particular reason? }\end{array}$ & 83 & 2 \\
\hline
\end{tabular}

\begin{tabular}{|c|c|c|}
\hline \multirow[t]{2}{*}{ Level of awareness } & \multicolumn{2}{|c|}{ Frequency } \\
\hline & YES & NO \\
\hline $\begin{array}{l}\text { Whether you increase the dosage } \\
\text { of the medication for the same } \\
\text { problem if you did not get relief? }\end{array}$ & 67 & 18 \\
\hline $\begin{array}{l}\text { Are you getting any satisfaction } \\
\text { while taking self-medication? }\end{array}$ & 58 & 27 \\
\hline $\begin{array}{l}\text { Before taking medication do you } \\
\text { check the expiry date? }\end{array}$ & 10 & 75 \\
\hline $\begin{array}{l}\text { Do you think whether the self } \\
\text { medication is useful? }\end{array}$ & 67 & 18 \\
\hline $\begin{array}{l}\text { Whether you will give self } \\
\text { medication to family members? }\end{array}$ & 42 & 43 \\
\hline $\begin{array}{l}\text { Do you read the content of the } \\
\text { medicine before taking? }\end{array}$ & 6 & 79 \\
\hline $\begin{array}{l}\text { Do you have any habit of taking same } \\
\text { medication for different symptoms? }\end{array}$ & 0 & 85 \\
\hline $\begin{array}{l}\text { Do you prefer self medication for } \\
\text { under five children? }\end{array}$ & 4 & 81 \\
\hline $\begin{array}{l}\text { Did you take self medication for } \\
\text { major illness? }\end{array}$ & 1 & 84 \\
\hline Did you keep medications in safe place? & 72 & 13 \\
\hline $\begin{array}{l}\text { Whether you keep the self medications } \\
\text { away from the children? }\end{array}$ & 83 & 2 \\
\hline $\begin{array}{l}\text { Whether you take self medication in your } \\
\text { antenatal period? }\end{array}$ & 20 & 65 \\
\hline $\begin{array}{l}\text { Do you know about the after effect of the } \\
\text { medication which you are consuming? }\end{array}$ & 10 & 75 \\
\hline $\begin{array}{l}\text { Whether you discard the left } \\
\text { over medications? }\end{array}$ & 14 & 71 \\
\hline $\begin{array}{l}\text { Did you experience any side effects } \\
\text { of self medications? }\end{array}$ & 4 & 81 \\
\hline $\begin{array}{l}\text { Have you stopped the self medication } \\
\text { after experiencing side effects? }\end{array}$ & 13 & 72 \\
\hline $\begin{array}{l}\text { Do you consult doctor after } \\
\text { experiencing side effects? }\end{array}$ & 13 & 72 \\
\hline $\begin{array}{l}\text { Have you experienced side effect } \\
\text { while increasing the dosage? }\end{array}$ & 4 & 81 \\
\hline $\begin{array}{l}\text { Do you consume any medications } \\
\text { to reduce side effects? }\end{array}$ & 6 & 79 \\
\hline $\begin{array}{l}\text { Are you aware that chronic dose } \\
\text { of self-medication can damage your liver? }\end{array}$ & & \\
\hline dose of self-medication can damage your liver? & 21 & 64 \\
\hline
\end{tabular}

\section{Level of Awareness}

The present study revealed that out of 85 homemakers 43 are having poor knowledge about self-medication and it's complications whereas 39 are having average knowledge and only 3 are having good knowledge. 


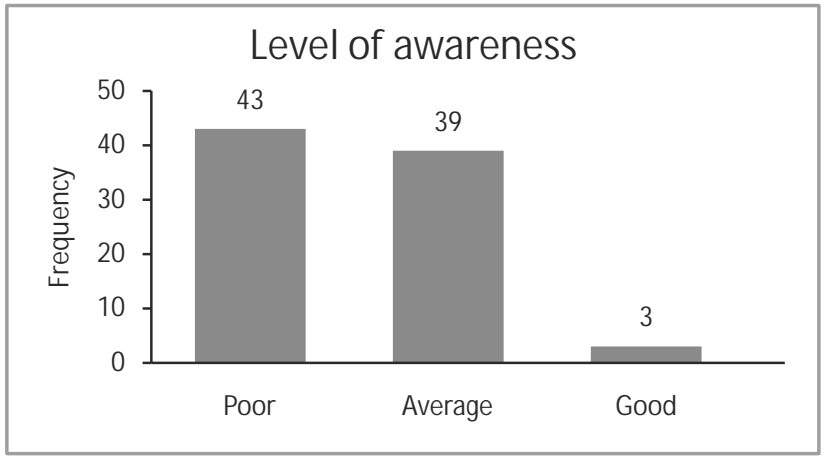

\section{Reference}

1. Suresh K Sharma. Nursing research and Statistics .2 nd edition .New delhi.Elsevier;2014

2. Banerjee TB. Self-medication practice among undergraduate medical students in tertiary care medical college,West Bengal. Journal of post graduate medicine.2012; 58(2);127-131.Available from http.//www. jpymonline.com/article.asp.

3. ZafarSN, Reema S, Sana W, Jaleel k ,Talba V. Self-medication amongst university students of Karachi: Prevalence, knowledge and attitudes. Journal of Pakistan M edical Association.April 2008.

4. Maryam A H, Seham M, and Seham Ali. Self-medication among undergraduate students in Kuwait with reference to the role of the pharmacist. Journal of research in pharmacy practice.Volume:3, Issue :1, Pages:23 - 27.

5. Umar M Lawan,Isa S Abubakar, Abubakar M Jibo and Ahmed Rufai .Pattern,awareness and perceptions of health hazards associated with self-medication among adult residents of Kano metropolis, Northwestern Nigeria. Indian journal of community medicine: 38(3),Pages:144 - 151

6. Devang P, Sattigeri BM, Kumar K, Brahmbhatt S. A survey on use of over -the -counter drugs medical students, nursing and clerical staff. International Journal of Research in M edical Sciences:1(1).

7. KP Osmene,A Lamikanra. A study on self-medication practice among university students in Southwestern Nigeria. Tropical of journal pharmaceutical research .Available from http://www.jptr.org.http: //dx.doi.org/10.431/jtpr.v 11 i 4.21.

8. Amareswara Reddy Gangula,Divyaja M ,Gowthami Reddy V,Samjeeva Kumar.A study on assessment of self-medication among rural village population. Journal of applied pharmacy. July 2014:6(3).

\section{Conclusion}

The findings of the study makes it clear that the prevalence of self-medication among homemakers is high despite of poor level of awareness about self-medication and it's complication i.e present study revealed that out of 85 homemakers 43 are having poor knowledge about selfmedication and it's complications whereas 39 are having average knowledge and only 3 are having good knowledge. 